\title{
Pengaruh Video Learning Multimedia Terhadap Sikap Siswi Dalam Menghadapi Menarche
}

\author{
The Effect of Video Learning Multimedia on Students' Attitudes in \\ Facing Menarche
}

\author{
Sitti Umrah ${ }^{1}$, Sri Ramadhany ${ }^{2}$, Muhammad Tamar ${ }^{3}$, Fenita Purnama Sari Indah ${ }^{4}$ \\ , Ernawati ${ }^{5}$ \\ 1,3 Magister kebidanan Seolah Pasca Sarjana Universitas Hasanuddin, Makassar \\ ${ }^{2}$ Fakultas Kedokteran Universitas Hasanuddin, Makassar \\ ${ }^{4}$ STIKes Kharisma Persada, Tangerang Selatan \\ ${ }^{5}$ Prodi DIII Kebidanan STIKes Karsa Husada Garut \\ Email : sittiumrah@pasca.unhas.ac.id
}

\begin{abstract}
ABSTRAK
Menarche bagi remaja putri adalah pertanda masa subur sudah dimulai. Sebagian remaja putri ketika mengalami menarche merasa takut dan merasa gelisah. hal ini disebabkan karena pemahaman remaja tersebut berpandangan bahwa haid adalah penyakit, serta dampaknya adalah dapat menimbulkan kecemasan. Penelitian ini bertujuan untuk menganalisisi penggunanaan media video learning multimedia tentang menarche terhadap sikap siswi dalam kesiapan menghadapi menarche. Penelitian ini merupakan quasy eksperimen (Noneequivalent Control Grup Design). Penelitian dilakukan di SD Inpres 1 dan SD Inpres IV Tamalanrea Kota Makassar pada bulan januari sampai februari 2020. Sebanyak 48 orang siswi kelas V dibagi menjadi dua kelompok yakni 24 orang kelompok kontrol (metode ceramah) dan 24 orang kelompok intervensi (media video learning multimedia dan ceramah) yang dipilih berdasarkan teknik purposive sampling. Data dianalisis dengan uji Wilcoxon. Hasil uji statistic menunjukkan pada kelompok control (p-value $0.001<0.05$ ) dan intervensi (p-value $0.001<0.05$ ) didapatkan perbedaan sikap yang signifikan setelah diberikan intervensi media video learning multimedia tentang menarche. Kesimpulan dalam penelitian ini adalah Penggunaan media video learning multimedia dan ceramah dapat meningkatkan sikap remaja putri dalam kesiapan menghadapi menarche. Namun siswa lebih tertarik dengan Penggunaan media video learning multimedia
\end{abstract}

Kata Kunci :Media Video Learning Multimedia,Ceramah, Sikap

\section{ABSTRACT}

Menarche for young women is a sign that the fertile period has started. Some young women when experiencing menarche feel afraid and feel anxious. this is due to the adolescent's understanding that menstruation is a disease, and its impact is that it can cause anxiety. This study aims to analyze the use of multimedia video learning media about menarche towards the attitudes of students in readiness to face menarche. This research is a quasy experiment (Noneequivalent Control Group Design). The research was conducted at SD Inpres 1 and SD Inpres IV Tamalanrea, Makassar City from January to February 2020. A total of 48 grade $\mathrm{V}$ students were divided into two groups, namely 24 in the control group (lecture method) and 24 in the intervention group (multimedia video learning media and lectures) were selected based on purposive sampling technique. Data were analyzed using the Wilcoxon test. The results of statistical tests showed that in the control group ( $\mathrm{p}$-value $0.001<0.05)$ and the intervention ( $\mathrm{p}$-value $0.001<0.05)$ there were significant differences in attitudes after being given the intervention of multimedia video learning media about menarche. The conclusion in this study is the use of multimedia video learning media and lectures can improve the attitude of young women in readiness to face menarche. However, students are more interested in the use of multimedia video learning media

Keywords: Media, Video Learning, Multimedia, Lectures, Attitudes 


\section{PENDAHULUAN}

Remaja menurut WHO adalah penduduk dalam rentang usia 10-19 tahun. Terdapat sekitar 1,2 milyar (18\%) penduduk dunia berusia remaja (Kementrian Kesehatan RI, 2015). Dalam Survey yang dilakukan leh SDKI (Survey Demografi Dan Kesehatan Indonesia) tahun 2012, dari sejumlah 19.399 responden dewasa muda yang diwawancarai, 10.980 adalah pria dan 8.419 adalah wanita $66 \%$ dari remaja yang berumur 15-19 tahun dan sisanya (34\%) berumur 20-24 tahun. Dari semua responden remaja wanita umur 15-24 tahun sangat sedikit yang belum pernah mendapatkan haid (0.3\%). 29\% remaja wanita mendapat haid pertama kali saat mereka berumur 13 tahun, dan $24 \%$ remaja wanita sudah mendapat haid pertama pada umur 14 tahun. Hampir separuh remaja wanita membahas mengenai haid dengan teman sebelum mereka mendapatkan haid pertama (SDKI, 2012)

Menarche bagi remaja putri adalah pertanda masa subur sudah dimulai. Sebagian remaja putri ketika mengalami menarche merasa takut dan merasa gelisah. hal ini disebabkan karena pemahaman remaja tersebut berpandangan bahwa haid adalah penyakit, serta dampaknya adalah dapat menimbulkan kecemasan. Selain itu sebagian remaja putri menganggap menarche sebagai suatu hal yang menakutkan, karena menarche menyebabkan rasa tidak nyama, nyeri, pusing, dan sebagainya. Kecemasan merupakan gejala psikologis yang muncul pada remaja putri yang mengalami menarche. Hal ini dapat timbul oleh keinginan untukmenolak proses fisiologis tersebut (Primastuti Widyaningrum, 2012).

Berdasarkan penelitian pada 155 remaja, yang dilakukan oleh Lee (2012) memperoleh sejumlah remaja tidak siap dalam menghadapi datangnya menarche, beberapa perassan yang dialami remaja tersebut yaitu merasa memalukann jijik,serta menganggap dirinya kotor, karena mendapati celananya penuh darah menstruasi.

Dalam penelitian lainnya yang dilakukan pada 50 responden didapatkan hampir seluruhnya $(76 \%)$ memiliki respon negatif dan sebagian kecil (24\%) memiliki respon positif dalam menghadapi menarche, respon negative responden diantaranya adalah merasa cemas, takut, sakit, dan malu dalam perubahan fisik yang dialaminya (Afiyah, 2016). 
Masalah menstruasi merupakan hal yang kurang dibicarakan bahkan cenderung tabu untuk didiskusikan dalam keluarga, dampaknya secara kognitif adalah kurangnya pengetahuan dan sikap remaja tentang menarche diantraranya yaitu perubahan fisik yang terjadi begitujuga secara psikologis remaja tidak siap dalam menghadapi menarche. Namun ha ini semakin parah apabila pengetahuan remaja mengenai menstruasi sangat kurang (Proverawati \& Misaroh, 2010).

Menarche pada anak usia sekolah penting untuk diperhatikan mengingat anak sudah memiliki kemampuan belajar, namun masih minim pengetahuan terkait hal tersebut. Melihat fenomena tersebut, peneliti tertarik meniliti tentang pengaruh pendidikan kesehatan dengan metode video learning multimedia tentang mentruasi terhadap kesiapan siswi Sekolah Dasar dalam menghadapi menarche.

Banyak metode yang dapat dilakukan dalam penyampaian informasi saat melakukan promosi kesehatan di sekolah.Pemilihan metode dalam pendidikan kesehatan juga berpengaruh terhadap persepsi yang mengubah perilaku seseorang terhadap sebuah informasi (Kholid, 2012). Beberapa metode yang dapat berpengaruh terhadap perilaku siswa diantaranya adalah model pembelajaran cooperative learning tipe CIRC (Cooperative Integratide Reading And Composition) (Al-hamdani, 2017), model Kooperatif Tipe Jigsaw terhadap Perilaku Kesehatan dan Keselamatan (Suryaningsih, 2020), model project based outdoor learning activity menggunakan media audiovisual terhadap perilaku belajar anak (Primayana, Dewi, \& Gunawan, 2020).

Salah satu metode yang dianggap tepat dan menarik adalam metode Video Learning Multimedia (VLM). Metode VLM adalah sebuah media pembelajaran berbentuk video, media dalam bentuk gambar yang bergerak ini merupakan alat pembelajaran yang modern dikalangan masyarakat. Segala informasi yang diberikan dalam bentuk gabungan dari suara, animasi, teks, video dan grafik adalah merupakan multimedia. Pembelajaran dengan menggunakan audio visual dapat meningkatkan kemampuan belajar siswa apabila dibandingakan dengan tanpa mempergunkan media. Maka dari itu didalam penelitian ini, peneliti lebih memilih media Video Learning Multimedia (VLM), karena 
dianggaplebih efisian dan lebih modern, serta diharapkan denganvideo learning multimedia tersebut pembelajaran dapat cepat diserap dan dipahami oleh (Munir, 2013).

Berdasarkan penelusuran awal yang telah dilakukan di SD Inpres Tamalanrea I dan IV pada tanggal 25 Oktober 2019 dengan jumlah siswi di tamalanrea I berjumlah 34 orang, sementara di SD Inpres Tamalanrea IV berjumlah 29 orang dilakukan wawancara dan pengisian identitas siswi kelas $\mathrm{V}$, berdasarkan hasil wawancara beberapa siswi menyatakan belum memahamihal yang perlu mereka lakukan saat menstruasi,mereka merasa cemas dan takut jika mengalami menstruasi.

Uraian diatas merupakan latar belakang peneliti dalam menganalisis Pengaruh Media Video Learning Multimedia Tentang Menarche Terhadap Sikap Siswi Kelas V dalam Kesiapan Menghadapi Menarche.

\section{METODE PENELITIAN}

Penelitian ini merupakan penelitian quasy eksperimen dengan nonequivalent control group desain. Responden dibagi menjadi dua kelompok yaitu kelompok control dengan metode ceramaha dan kelompok intervensi dengan metode ceramah video learning multimedia. Pre-test dan posttest dilakukan masing-masing satu kali. Sampel dalam penelitian ini adalah siswi kelas V sebanyak 48 sampel, 24 sampel pada kelompok control dan 24 sampel pada kelompok intervensi. Dengan kriteria inklusi antara lain belum mengalami menarche, usia 10-12 tahun, bersedia mengikuti proses penelitian sampai selesai. Penelitian ini dilakukan dengan menggunakan media video learning multimedia dan instrument yang digunakan yaitu kuesioner. Analisis dalam penelitian ini menggunakan uji statistic, uji homogenitas of variance untuk menilai distribusi data pada kedua kelompok dan uji Wilcoxon untuk menilai adanya pengaruh intervensi yang dilakukan dalam penelitian ini.

\section{HASIL DAN PEMBAHASAN}

Sejumlah 48 orang siswi kelas V SD Inpres tamalanrea I dan IV yang memenuhi kriteria inklusi dipilih menjadi sampel penelitian. 24 sampel di SD Inpres Tamalanrea $1 \mathrm{~V}$ sebagai kelompok interensi (Video Learning Multmedia). dan 24 sampel di SD Inpres Tamalanrea I sebagai kelompok control 
(Ceramah). Penelitian ini bertujuan untuk mengetahui apakah ada pengaruh video learning multimedia tentang menarche terhadap pengetahuan dan sikap siswi kelas V dalam kesiapan menghadapi menarche.

Tabel 1.Distribusi karateristik Responden

\begin{tabular}{llcc}
\hline Karekteristik & $\begin{array}{l}\text { Kelompok Kontrol } \\
\mathbf{f}(\%)\end{array}$ & $\begin{array}{l}\text { Kelompok Intervensi } \\
\mathbf{f}(\%)\end{array}$ & p-value* \\
\hline Usia & $14(58.3)$ & $11(45.8)$ & 0.590 \\
$\quad 10$ tahun & $10(41.7)$ & $13(54.2)$ & \\
$\quad$ I1 tahun & $17(70.8)$ & 0.083 \\
$\quad \begin{array}{l}\text { Tinggal Bersama Ibu } \\
\text { Ya }\end{array}$ & $22(91.7)$ & $7(29.2)$ & \\
$\quad$ Tidak & $2(8.3)$ & & \\
Memiliki Kakak & & $9(37.5)$ & 0.572 \\
perempuan & $14(58.3)$ & $15(62.5)$ & \\
$\quad$ Ya & $10(41.7)$ & & \\
$\quad$ Tidak & & $9(37.5)$ & 0.266 \\
Informasi tentang & $10(41.7)$ & $15(62.5)$ & \\
Menarche & $14(58.3)$ & & \\
$\quad$ Ya & & & \\
$\quad$ Tidak & & & \\
\hline
\end{tabular}

*Uji Homogenity Of Variance

Tabel di atas memperlihatkan karakteristik responden yang dominan sama atau homogen. Berdasarkan umur, kedua kelompok cenderung berumur 1011 tahun,kelompok control persentasenya $58.3 \%$ dan kelompok intervensi $45.8 \%$, dan usia 11 tahun pada kelompo control 41.7\%, intervensi $52.2 \%$ dengan nilai $p$-value $0.590>0.05$. dan cenderung tinggal bersama ibu mereka, pada kelompok control mencapai $91.7 \%$, intervensi $70.8 \%$ dan yang tidak tinggal bersama Ibu (orang tua) pada kelompok control $8.3 \%$, intervensi 29.25 dengan nilai $p$-value $0.83>0.05$.
Jika dilihat dari apakah responden memiliki kakak perempuan dominan responden memiliki kakak perempuan, kelompok control persentasenya $50.3 \%$, intervensi $37.5 \%$ dan yang tidak memiliki kakak perempuan pada kelompok control $41.7 \%$, intervensi 62.55 dengan nilai $p$ value $0.572>0.05$. Berdasarkan informasi tentang menstruasi sebelumnya kedua kelompok cenderung belum pernah terpapar informasi tentang menstruasi, kelompok control yang mendapat informasi sebelumnya yaitu $41.7 \%$, intervensi $37.5 \%$ dan yang tidak mendapat informasi pada kelompok 
control $58.3 \%$, intervensi $62.5 \%$ dengan

nilai $p$-value $0.266>0.05$.

Tabel 2.Perbedaan Pengetahuan dan Sikap Pre dan Post pada Kelompok Kontrol danKelompok Intervensi di SD Inpres Tamalanrea I dan SD Tamalanrea IV Kota Makassar.

\begin{tabular}{llll}
\hline Variabel & & Kontrol & $\begin{array}{c}\text { Kelompok } \\
\text { Intervensi }\end{array}$ \\
\hline \multirow{3}{*}{ Sikap Pre Test } & p-value & $<\mathbf{0 . 0 0 1}$ & $<\mathbf{0 . 0 0 1}$ \\
$\&$ & Menurun & 4 & 3 \\
Sikap Post Test & Meningkat & 18 & 20 \\
*Uji Wilcoxon & Menetap & 2 & 1 \\
\hline
\end{tabular}

Hasil uji statistic pada uji pre-test dan post-test sikap pada kelompok control yang kategori menurun 4 responden,meningkat $\quad 18$ responden,menetap 2 responden dan pada kelompok intervensi kategori menurun 3 responden meningkat 20 responden dan menetap 1 responden dengan nilai p-value $0.001<0.05$. ditunjang oleh sebaran data yang menunjukkan peningkatan sikap responden sebelum intervensi diberikan dan sikap responden setelah intervensi diberikan baik kelompok kontrol maupun kelompok intervensi.

Hasil uji statistik pada sikap yang didapatkan pada variable kelompok kontrol dan kelompok intervensi $<0.05$.perubahan yang signifikan cenderung pada kelompok intervensi.

$$
\text { Pada kategori sikap }
$$
menunjukkan ada pengaruh sebelum intervensi dan intervensi sesudah diberikan dengan menggunaka media video learning multimedia dengan $p$ value $0.000<0.05$. pada pre-test responden dengan sikap positive memiliki persentase sebesar 5 (20.8) setelah dilakukan post test persentase menjadi 17 (70.8) yang kategori sikap positive.

Beberapa faktor yang mempengaruhi perubahan sikap pada penelitian ini lebih signifikan pada kelompok intervensi karena media yang digunakan yakni video learning multimedia, dibandingkan dengan metode ceramah yang monoton dan bahkan setiap hari metode ceramah ini dirasakan oleh siswi saat guru mereka mengajar dikelas. Materi dengan alat bantu video responden akan lebih focus sejak dimulainya pemberian materi sampai dengan berakhirnya pemberian materi. 
Dikutip dari Notoatmodjo, 2014 Sikap adalah rangkaian kumpulan gejala dalam merespons stimulus atau objek. Sikap memerlukan pikiran, perasaan, dan perhatian. Sikap terbagi menjadi 4 yaitu menerima (receiving), Merespon (responding), Menghargai (valuing), dan Bertanggung jawab (responsible).

Penggunaan media pembelajaran video lerning memudahkan membuat siswa tertarik belajar dan dampaknya mempengaruhi sikap siswa dalam mempersiapkan diri untuk menghadapi menarche, beberapa peneilitan juga menunjukkan bahwa penggunaan metode pembelajaran mampu meningkatkan keaktifan dan motivasi belajar siswa diantaranya adalah penggunaan metode pembelajaran berbasis masalah(Ahmar, Budi, Ahmad, Mushawwir, \& Khaidir, 2020; Farisi, Hamid, \& Melvina, 2017) selain itu pembelajaran dengan metode discovery learning berpengaruh terhadap hasil belajar siswa (Setiyowati \& Panggayuh, 2019).

Khusus penggunaan metode video learning dan pengaruhnya terhadap sikap dalam penelitian ini didukung oleh beberapa hasil penelitian diantaranya adalah penelitian yang dilakukan (Ramadinata, Sudatha, \& Parmiti, 2020)mardika dalam penelitiannya juga menunjukkan adanya hubungan antara penggunaan metode pembelajaran dengan media video learning terhadap peningkatan pengetahuan dan perubahan sikap pelajar SMA di Malang (Mardika, 2019)

Sikap merupakan suatu tidakan atau aktifitas yang memerlukan kesiapan untuk bereaksi terhadap objek serta suatu penghayatan tehadap objek.penelitian yang dilakukan oleh Alini dan Indrawati, 2018 dari hasil penelitian yang dilakukan dapat diketahui bahwa hasil iji statistic dengan menggunakan promosi kesehatan (SADARI) dengan menggunakan video didapatkan nilai $p$ value 0.003 . Artinya terdapat pengaruh sikap tentang promosi kesehatan (SADARI) pada remaja di SMAN 1 Kampar.

Penelitian dilakukan oleh Yessy Lelasari, 2017 hasil penelitian menunjukkan siswi yang sudah menstruasi sebelummemperolehhealth education tentang kebersihan diri saat menstruasi nilai persentase sikap sebesar 67.86,kemudian setelah diberikan health education dengan video learning nilai persentase sikap meningkat sebesar 72.85. Nilai signifikan sikap $0.000<0.05$. 
Kemampuan media video dalam menarik perhatian menjadi bagian penting dalam proses persuasi dalam diri individu agar terjadi perubahan pengetahuan, sikap. Penggunaan media pembelajaran berbasis audio visual dapat meningkatkan kemampuan berfikir kritis responden (Wahyudi, 2016)

Penggunaan media video learning multimedia dapat mendukung remaja/siswi dalam persiapan menghadapi menarche, hal ini sejalan dengan beberapa penelitian sebelumnya diantaranya yang memperoleh hasil bahwa dalam menghadapi menarche kesiapan remaja dipengaruhi oleh informasi yang diperoleh dari media televisi,radio, majalah,atau yang lainnya (Lutfiya, 2017)Media video dengan tujuan sebagai alat bantu pendidikan berfungsi persuasive dalam upaya pengendalian pengetahuan, sikap dan perilaku penonton, bukan hanya mmberikan fungsi hiburan (Munadi, 2013)

Penggunaan media video dalam upaya pengubahan pengetahuan dan sikap dapat terjadi karena media video memiliki beberapa kelebihan yaitu menarik perhatian, menghadirkan yang realistic berupa gambar, memperjelas hal-hal yang abstrak, penggunaan teknik dan efek tertentu yang memengaruhi emosi seseorang serta dapat menggambarkan suatu peristiwa secata tepat (Daryanto, 2010).

Asumsi peneliti mengenai media video learning multimedia sangat evektif dalam meningkatkan sikap siswi khususnya bagi yang menjadi responden dalam penelitian ini karena pada usia mereka dan kondisi saat ini yang serba digital maka proses pembelajaran yang mereka terima setiap hari yang terbilang monoton akan terasa membosankan, dengan adanya metode baru dalam edukasi kesehatan ini maka membangkitkan semangat dan minat belajar mereka dengan metode yang baru, dan tentunya materi yang disajikan merupakan materi edukasi yang memang mereka butuhkan saat ini.

\section{SIMPULAN DAN SARAN}

Terdapat perubahan sikap siswi dalam kesiapan menghadapi menarche serta perbedaan yang signifikan antara persentase nilai sikap siswi kelas V dalam kesiapan menghadapi menarche.

\section{DAFTAR PUSTAKA}

Afiyah, R. K. (2016). Gambaran Respon Psikologis Saat Menarche Pada Siswi Kelas 4-6 SD khadijah Surabaya. Jurnal Ilmu Kesehatan, 9(2), 209-214. 
Ahmar, H., Budi, P., Ahmad, M., Mushawwir, A., \& Khaidir, Z. (2020). Jurnal Keperawatan Muhammadiyah Penerapan Model Pembelajaran Problem Based Learning : Literature Review.

Al-hamdani, H. M. D. (2017). Pengaruh Model Pembelajaran Kooperatif Tipe Cooperative Integratide Reading And Composition Terhadap Perilaku Sosial Dan Spiritual Siswa. Jurnal Penelitian Pendidikan Islam, 5(1).

Daryanto (2010). Media Pembelajaran. Yoryakarta. Gava Medika.

Farisi, A., Hamid, A., \& Melvina. (2017). Pengaruh Model Pembelajaran Problem Based Learning Terhadap Kemampuan Berpikir Kritis Dalam Meningkatkan Hasil Belajar Siswa Pada Konsep Suhu Dan Kalor. Jurnal Ilmiah Mahasiswa (JIM) Pendidikan Fisika, 2, 283-287. Retrieved from http://jim.unsyiah.ac.id/pendidikan -fisika/article/view/4979/2336

Kholid, Ahmad, 2012. Promosi Kesehatan dengan pendekatan teori prilaku, media, dan aplikasinya. Perpustakaan Nasional: Katalog Dalam Terbitan (KDT). Jakarata : Rajawali Pers.

Khoirunnisa E. Sumber-Sumber Informasi Tentang Kesehatan Reproduksi dengan Kesiapan Menghadapi Menarche. Jurnal Ilmu Kebidanan, 2014 (2) 1.

Lee, S. J. (2012). Parental restrictive mediation of children's internet use: Effective for what and for whom?. New Media and Society, 15(4), 466-481.

Lutfiya, I. (2017). Analisis Kesiapan Siswi Sekolah Dasar dalam Menghadapi Menarche. Jurnal Biometrika Dan Kependudukan, 5(2), 135. https://doi.org/10.20473/jbk.v5i2.2 016.135-145

Mardika, R. (2019). Pengaruh Pendidikan Kesehatan Tentang BLS Menggunakan Media Video Dan Metode Demonstrasi CPR Terhadap Tingkat Pengetahuan Dan Sikap Siswa SMA. Repository $U M M, 8(5), 55$.

Munir, (2013). Multimedia dan Konsep Aplikasi Dalam Pendidikan. Bandung: Penerbit Alfabeta

Notoatmodjo, Soekidjo, 2014, Metodologi Penelitian Kesehatan. Edisi revisi. Jakarta: PT. Rineka Cipta

Primayana, K. H., Dewi, P. Y. A., \& Gunawan, I. G. D. (2020). Pengaruh Project Based Outdoor Learning Activity Menggunakan Media Audiovisual Terhadap Perilaku Belajar Anak Di PAUD. Jurnal Pendidikan Anak Usia Dini, 5(2), 135-146.

Ramadinata, I. P. S., Sudatha, I. G. W., \& Parmiti, D. P. (2020). Pengaruh Model Pembelajaran Cycle 5E Berbantuan Media Video Terhadap Sikap Sosial. Jurnal Penelitian Dan Pengembangan Pendidikan, 4(2), 158.

https://doi.org/10.23887/jppp.v4i2. 27336

Riset Kesehatan Dasar. (2010). Jakarta: 
Badan Penelitian dan Pengembangan Kesehatan Kementrian Kesehatan RI

SDKI. (2012), Laporan Pendahuluan Masalah Kesehatan Reproduksi Pada Remaja. Pusat Statistik; BKKBN . Jakarta.

Setiyowati, P., \& Panggayuh, V. (2019). Pengaruh model pembelajaran discovery learning menggunakan video scribe sparkol terhadap hasil belajar SMK Perwari Tulungagung kelas X tahun ajaran 2017/2018. JOEICT (Jurnal of Education and Information Communication Technology), 3(1), 12-21.

Suryaningsih, A. (2020). Pengaruh Penerapan Pembelajaran Kooperatif Tipe Jigsaw terhadap
Perilaku Kesehatan dan Keselamatan Anak. Jurnal Obsesi : Jurnal Pendidikan Anak Usia Dini, 5(2), 1063-1072. https://doi.org/10.31004/obsesi.v5i 2.751

Wahyudi, A. (2016). Pengembangan media audio visual berbasis sejarah perjuangan Adisutjipto untuk meningkatkan sikap kritis siswa dalam pembelajaran sejarah di sma angkasa .... Retrieved from https://digilib.uns.ac.id/dokumen/d etail/57298/Pengembangan-mediaaudio-visual-berbasis-sejarahperjuangan-Adisutjipto-untukmeningkatkan-sikap-kritis-siswadalam-pembelajaran-sejarah-disma-angkasa-AdisutjiptoYogyakarta 